\title{
Counseling over Time as a Correlate of Non-Urgent Undergraduate Institutional Commitment
}

\author{
Gary Blau ${ }^{1}$, John DiMino ${ }^{2}$, Iris Abreu ${ }^{2} \&$ Kayla LeLeux-LaBarge ${ }^{2}$ \\ ${ }^{1}$ Human Resource Management Department, Fox School of Business, Temple University, Philadelphia, USA \\ ${ }^{2}$ Tuttleman Counseling Services, Temple University, Philadelphia, USA \\ Correspondence: Gary Blau, Human Resource Management Department, Temple University, 349 Alter Hall, 1810 \\ Liacouras Walk, Philadelphia, PA, 19122, USA. E-mail: gblau@temple.edu
}

Received: August 9, 2017

Accepted: August 22, 2017

Online Published: September 20, 2017

doi:10.5539/jedp.v7n2p96

URL: http://doi.org/10.5539/jedp.v7n2p96

\begin{abstract}
The general purpose of this study was to examine counseling services as a correlate of institutional commitment and related variables over time on a sample of non-urgent undergraduates. Data for non-urgent clients at a University Counseling Center (UCC) were collected using on-line surveys over four time-periods. Within-time correlations generally showed that mental health concerns was negatively related to institutional commitment, while counseling help belief was positively related. Institutional commitment is defined as a student feeling that he or she selected the right institution to attend Using a smaller sample, i.e., $\mathrm{n}=15$, of complete-data clients matched-over-time, overall level of mental health concerns significantly declined, while institutional commitment significantly increased. Counseling help belief decreased from Time 1 to Time 2 but then increased over time. Scientifically demonstrating to higher-level University administration that counseling over time can positively influence undergraduates' institutional commitment can help the UCC to increase its allocation of university-based resources to keep pace with non-urgent client demands.
\end{abstract}

Keywords: counseling impact, institutional commitment, mental health concerns, non-urgent undergraduates, unlimited sessions

\section{Introduction}

The 2016 annual report by the Center for Collegiate Mental Health (CCMH, 2017), which collected data across 139 University Counseling Centers (UCCs), noted a continuing increase in the demand for mental health services. A supplemental survey of CCMH (2017) UCCs also found that, "on average UCCs are providing $28 \%$ more 'rapid-access' service hours per client and 7.6\% fewer 'routine' service hours per client over the last six years" (p. 3). The report goes onto say that:

This shift, especially in centers with funding models that don't increase with demand, may impact the availability of routine services after the initial contact. Therefore, colleges and universities are encouraged to specifically attend to routine treatment capacity (not just the speed of initial response) as they consider responding to growing demand for mental health services in higher education (CCMH, 2017, p. 3).

The general purpose of this study was to examine counseling services as a correlate of institutional commitment and related variables over time on a sample of non-urgent undergraduates. This is an important issue to consider as UCCs compete for university resources with other campus stakeholders (Hunt, Watkins, \& Eisenberg, 2012).

\subsection{Why Focus on Institutional Commitment?}

UCCs have typically reported research focused on evaluating their services, including: client satisfaction (Maffini \& Toth, 2017), as well as other standardized mental health measures such as the: Behavioral Health Measure or BMH (Kopta et al., 2014), and Counseling Center Assessment of Psychological Symptoms or CCAPS (Brunner, Wallace, Reymann, Sellers, \& McCabe, 2014). While gathering such mental health data is certainly important, 20 years ago Corazzini (1997, p. 380) noted that "the future of a counseling center is more promising when counseling is seen in relation to the academic mission". Archer and Cooper (1998) argued that providing services that were integrated with academic goals is one of the great challenges for a UCC. In addition to academic performance, fostering student commitment to the institution, via their engagement, is generally an important component of a 
university/college's academic mission (Kezar \& Kinzie, 2006). As an example of meeting this challenge, Coll and Stewart (2002) found that counseling services increased College of Education undergraduates' academic integration and social integration, as well as their teaching ability confidence. Research has long-argued (Tinto, 1975) that two forms of commitment - goal and institutional, are the immediate antecedents of undergraduate dropout decisions. Empirical research (Bean, 1980; Reason, 2009) has found that institutional commitment, i.e., feeling that you selected the right institution to attend (Davidson, Beck, \& Milligan, 2009), is the most proximal antecedent of undergraduate retention. While research has shown that counseling has increased student retention (Lee, Olson, Locke, Testa Michelson, \& Odes, 2009; Wilson, Mason, \& Ewing, 1997), there has been less research investigating the relationship of counseling to client institutional commitment.

\subsection{Correlates of Institutional Commitment}

As noted above, institutional commitment would be expected to have a direct impact on retention rates. Given the difficulty of collecting student records, "intent to graduate" has often been used as a proxy for retention (e.g., Davidson et al., 2009; Hausmann, Ward Schofield, \& Woods, 2007). When comparing Not-In-Counseling (NIC) with Initial Counseling Session (ICS), i.e., post-triage, pre-intake non-urgent undergraduate samples, Blau, DiMino, DeMaria, Beverly and Chessler (in press-a) found that institutional commitment was positively related to and explained additional significant variance in intent to graduate beyond controlled-for demographic variables (i.e., gender, ethnic background, residential status, parents' education, self-report GPA, and age) for both samples.

Why would counseling have a relationship to clients' institutional commitment? Using various pre-counseling and post-counseling measures, Brunner et al. (2014) called today's undergraduates the "most stressed" generation of college students (p. 264). When simultaneously comparing in-counseling versus not-in-counseling undergraduate samples, researchers have reported that students who are in-counseling have lower perceived well-being and mental health (Green, Lowry, \& Kopta, 2003). College students with higher perceived psychological distress were less likely to persist towards graduation (Kitzrow, 2009). The perceived responsiveness of the institution, i.e., how/when it takes care of/attends to its' students, may be acutely significant when a student feels vulnerable and in need of help (Mowbray et al., 2006). For such a student, the UCC therapist can partially represent the institution, and the therapeutic alliance, i.e., collaborative and affective bond between therapist and patient, has been shown to affect subsequent treatment improvement (Bergin \& Garfield, 2013). Pinkerton, Tally, and Cooper (2009) noted the benefits of open-ended psychotherapy, which allowed the client to work through developmental milestones over a period of time (e.g., leaving home, selecting a major, defining a career), as well as upheavals (e.g., break up of an intimate relationship, family death). This research collectively suggests that level of mental distress, mental health concerns, belief in counseling helping, and intent to graduate are correlates of institutional commitment.

\subsection{Generally Brief Nature of College Counseling}

Given the increased demand for mental health services on many university campuses (Gallagher, 2014), and the typical way that college students use such services, counseling is typically of short duration. Using the data gathered from 1,698 college student clients across 42 universities, Draper, Jennings, Baron, Ozgur, and Shankar (2002) found that the average number of sessions per client was 3.3. In another review, Ghetie (2007) noted a median of 4-5 counseling sessions and a mode between 1 and 2 sessions. Mahon et al. (2015) found that 37/124 $(30 \%)$ of undergraduate clients completed a minimum of three counseling sessions, with the remaining 87 either never returning for a second session or dropping out after two sessions. The $2016 \mathrm{CCMH}$ report (CCMH, 2017) noted a mode of 1 for the number of appointments and an average of 5.84 sessions, while the 2016 Association for University and College Counseling Directors or AUCCD report (AUCCD, 2016) reported an average of 5.53 sessions/client.

While it can be very challenging to build a longer-term sample of undergraduates receiving counseling services, prior research suggests that even a short-term intervention can increase important undergraduate outcomes. Mahon et al. (2015) found a significant decrease in counselor-reported client symptom severity. Blau et al. (2016) found that the means of social connectedness and life satisfaction significantly increased over time for 28 non-urgent undergraduates, with a median of four counseling sessions (after initial triage assessment).

\subsection{Longer-Duration College Counseling}

Surette and Shier (2017) worked with 102 clients for a mean of seven sessions over an average of 18 weeks, and assessed the outcomes of somatization, depression, and anxiety. They found that duration of therapy, positive life events, and intimate relationship supports positively influenced outcomes, while both an increased number of intervention approaches and sessions each had a negative influence. In a two-part study over three years, Lucas 
(2012) first compared three groups of non-urgent undergraduate clients: no-show first session ( $\mathrm{n}=492)$; stopped before improvement $(n=396)$, and counseling completers $(n=1,042)$, and found that completers compared to the other two groups, reported at intake higher levels of confidence that counseling will help, degree of well-being, and life functioning. Study 2 (Lucas, 2012) focused on students $(n=75)$ who received at least eight counseling sessions and found that students who rated themselves as highly distressed $(n=47)$ versus less distressed $(n=28)$ at intake reported the most benefits. Kopta et al. (2014) used a data set of 13,803 clients on the Behavioral Health Measure-20 (BMH-20) across 23 UCCs in the United States from 2006-11 to show that client treatment benefit on the BMH-20 peaked between 7 to 10 sessions.

Using a smaller sample of 20 matched-over-three time-periods non-urgent clients, Blau, DiMino, Abreu, and LeLeux-LaBarge (in press-b) found that levels of mental distress and mental health concerns significantly declined, while life satisfaction significantly increased. The three time periods were over a period of ten weeks (range 8 to 12 weeks), with a median of six counseling sessions after intake (range less than 5 to 12). The current study focused on a different outcome than (Blau et al., in press-b), i.e., institutional commitment, and it is also different from Blau et al. (in press-a) by testing a new independent variable (counseling help belief). The current study looked at the relationship of counseling with a greater number of sessions over a longer time period then these two prior (Blau et al., in press-a; Blau et al., in press-b) studies. Prior research with UCC clients (Wolgast, Lambert, \& Puschner, 2004) has shown that the number of sessions affected clinically significant change, with 14 sessions required for $51 \%$ of clients to meet this change criteria. Clinically significant change was defined by "when a client's final Outcome Questionnaire or OQ-45 (Lambert et al., 1996) was equal or less than 63 and had decreased by at least 14 points from the intake session" (Wolgast et al., p. 21). The OQ-45 measures symptoms of psychopathology, interpersonal problems, and social role functioning difficulties. With a focus on institutional commitment as the main study variable, the four hypotheses for this study were:

H1-Level of mental distress and mental health concerns will be negatively related, while counseling help belief will be positively related, to institutional commitment

\section{H2-Institutional commitment is positively related to intent to graduate}

\section{H3-Brief counseling will increase intent to graduate}

H4-Over a longer period of time counseling will reduce the level of mental distress and mental health concerns and increase counseling help belief and institutional commitment

\section{Method}

\subsection{Samples and Procedures}

Four undergraduate samples based on length of time in counseling were collected in this study. All data were voluntarily collected using on-line surveys at the main campus of a large state-supported urban university's UCC in the Mid-Atlantic region of the United States. The first sample is labeled as initial counseling session sample or Time 1. All three subsequent samples were derived from this initial sample and are labeled Time 2 and Time 3 and Time 4. However, for any given client, the nature of their mental issue, as well as client/therapist availability did not allow for a standardized number of sessions or time periods to represent when clients filled out the subsequent surveys. Given this non-standardized time-period and number of counseling sessions provided for participants before taking subsequent surveys, a range of sessions and time-periods were used (reported below).

Data were collected for 332 undergraduates who registered for counseling services at the UCC between the Fall of 2013 through the Spring of 2017. Institutional Review Board approval was given for all data collection, and data went directly into Qualtrics' data bases. These undergraduate students had been designated at their initial counseling session (i.e., an in-person triage interview), as non-urgent (non-suicidal or no risk to self/others) by the triage therapist. Students were asked by the triage therapist if they wished to voluntarily participate in a research study looking at the impact of counseling on student outcomes. The Time 1 clients took their survey after triage but before beginning counseling (i.e., intake). The time span between triage and intake could be anywhere from that week to over two to three weeks, depending on current client demand for services and therapist availability. Sample demographics for the Time 1 complete-data sample are reported below.

Undergraduate clients who filled out the initial survey (Time 1) were given the option of listing the last four digits of their nine-digit university identity number so that their responses, while receiving counseling, could be tracked over time while their individual identities would remain protected. Clients could take the Time 1 survey either at the UCC's self-help center or at home using a survey link. Using their email addresses recorded at triage, clients were contacted after their triage appointment at four week intervals, i.e., at Time 2 (four weeks from triage), Time 
3 (eight weeks from triage), and Time 4 (12 weeks from triage). A general email was sent out to all post triage clients on a rolling weekly basis during a semester. As a check, clients were asked what survey they were filling out (Time 1, Time 2, Time 3, Time 4). Given the volume of clients involved, and the anonymity of respondents (using only the last 4-digits), it was not determined if a particular client had stopped coming to the UCC.

Of the 332 initial participants, 211 (64\%) filled out all the Time 1 survey data and are designated as Time 1. A sample of $\mathrm{n}=64 / 211$ (39\%) filled out a second survey at Time 2. This Time 2 sample reported a median of three counseling sessions after intake (range 1 to 8 ) over a median period of six weeks (range 4 to 10 weeks). Of the Time 1 clients, $\mathrm{N}=48 / 211$ (23\%) filled out the third survey or Time 3. This Time 3 sample reported a median of six counseling sessions after intake (range less than 5 to 12) over a median period of ten weeks (range 8 to 12 weeks). Finally, for Time 4,31/211 (15\%) filled out the fourth survey, reporting a median of nine counseling sessions after intake (range less than 9 to 15) over a median period of fourteen weeks (range 12 to 20 weeks). Thus there is a client participation rate decline from $\mathrm{N}=211$ (Time 1) to $\mathrm{N}=64$ (Time 2) to $\mathrm{N}=48$ (Time 3) to $\mathrm{N}=31$ (Time 4). In order to improve the longitudinal response rate a $\$ 50$ random-drawing lottery for matched ID repeat-respondents was approved by the IRB part-way through the data collection process. However, this incentive had little impact in improving the matched respondent participation rate. Across all four time periods there were only 15 clients who matched across time, when using their four-digit identification number. This four-time match sample $(\mathrm{N}=15)$ will be called the complete sample.

\subsection{Measures}

Respondent demographics. Demographics were collected only at Time 1. Data collected were: main mental health issue for presenting to counseling, gender (male/female/transgender), ethnic background (non-white/white), status entering university (no transfer/transfer, i.e., did the student start at the university as a freshman versus transfer in at some later point), current residential status (non-commuter/commuter), parents' highest education level, self-reported Grade Point Average (GPA), age, referral source for counseling (self/other), days waited for intake (after triage) and status as a full-time student (taking at least 12 credits/semester).

Level of mental distress, mental health concerns, counseling help belief, institutional commitment, and intent to graduate. Unless otherwise noted, all items were measured using a seven-point Likert scale, where $1=$ strongly disagree to $7=$ strongly agree. These variables were measured at all four times, except for intent to graduate which was only measured at Time 1 and 2. Level of mental distress was measured by asking clients to "rate your current level of mental distress that brought you to counseling". An eight-point Likert response scale was used, where: $1=$ none, $2=$ very little, $3=$ a little, $4=$ moderate, $5=$ a lot, $6=$ severe, $7=$ very severe, $8=$ unbearable. Mental health concerns were measured using six items. Items were "I have recently: (1) lost a lot of sleep over worrying, (2) felt constantly under some type of strain, (3) felt that I could not overcome my difficulties, (4) been feeling unhappy or depressed, (5) been losing confidence in myself and (6) been thinking of myself as a worthless person." These six items represent the Symptoms of Mental Disorder factor in the short-form of the General Health Questionnaire (Hu, Stewart-Brown, Twigg, \& Weich, 2007). The 4-point response scale used by $\mathrm{Hu}$ et al. (2007, p. 1006) was expanded to a 7-point response scale to keep response scale consistency. The higher the total score the greater one's mental health concerns. Blau et al. (in press-a) found the Cronbach's alpha was .91 NIC sample and .80 for the ICS sample.

Belief in counseling helping (Counseling Help Belief) was measured using six study-specific items, "I believe that counseling will help me to: (1) better cope with difficult situations I have, (2) more successfully deal with the life challenges I face, (3) interact with others more successfully, (4) learn how to better manage my negative thinking, (5) understand how my prior learned thought patterns may be contributing to my current concerns, and (6) reaffirm my inner personal strengths." These items were partially based on the qualitative analyses about what clients felt was helpful about counseling, e.g., client resolutions, new perspectives, gaining knowledge, emotional relief (Paulson, Truscott, \& Stuart, 1999). Previous research (Blau et al., 2015) found an internal consistency reliability of this scale (coefficient alpha) was .92. Institutional commitment was measured using three of four items (Davidson et al., 2009). Items were: "(1) I am sure University X is the right place for me, (2) I am confident that I made the right decision to attend University X, and (3) I have no plans to transfer/leave University X." The fourth item was not used because it mentions "earning a degree", which potentially overlaps with intent to graduate. The Cronbach's alpha was .86 for both the NIC and ICS samples (Blau et al., in press-a). Intent to graduate was measured using three items. Items were: "(1) I intend to persist in getting a college degree, (2) I am confident that I will graduate with a degree, and (3) no matter what it takes, I am committed to getting my college degree." These items were adapted from prior research (Davidson et al., 2009; Hausmann et al., 
2007). The higher the total score the greater one's intent to graduate. The Cronbach's alpha was .92 for the NIC sample and .88 for the ICS sample (Blau et al., in press-a).

\subsection{Data Analyses}

All data analyses were done using SPSS-PC (SPSS, 2013). The two hypotheses (H1 \& H2) were tested using within-time period Pearson correlation analyses for complete data samples on the variables involved. The third hypothesis (H3), involving only intent to graduate over two time periods, was tested using a paired samples t-test. The fourth hypothesis (H4) was tested using the General Linear Model (GLM) for each of the four variables across four time periods. The GLM was appropriate for a repeated measures design (Stevens, 1996). There was no homogeneity of variance test with the GLM because only one group, i.e., the complete sample, was used. However, Mauchly's sphericity test, which is appropriate for three or more levels of a repeated measure factor (i.e., time), was calculated prior to testing between group differences (Stevens, 1996). A non-significant test indicated that the variances of the differences between all possible pairs of within-subject conditions (i.e., levels of independent variable or four different times) was equal and the subsequent multivariate F test was not inflated. For each GLM test, Mauchly's sphericity test was not significant, supporting the subsequent multivariate F test reported. If a significant multivariate $\mathrm{F}$ was found, the least squares difference post hoc test between groups was then used (Stevens, 1996). Since direction was specified in H4, an a priori one-tail test is justified (Stevens, 1996). Effect size for the largest significant difference between groups within a variable was also reported (Cohen, 1988).

\section{Results}

\subsection{Demographic Comparison of Complete to Initial Sample}

Table 1 shows a demographic comparison of the complete-data Time 1 sample $(\mathrm{n}=211)$ to the Time 4 sample $(\mathrm{n}=$ 31). Overall, there was general consistency between the two samples, although the percentage of males by Time 4 had noticeably dropped while, the percentages of female and transgender clients had increased. Sample participants reporting anxiety and depression as the two main mental health issues for coming to the UCC was consistent with the AUCCD (2016) and CCMH (2017) reports. However, the complete data respondent percentage reporting anxiety at Time 4 had risen considerably from Time 1 . Anxiety seemed to be a stronger mental health issue for non-urgent clients staying longer in counseling. The UCC sample participant base of primarily white female was also consistent with these two reports.

Table 1. Demographic variable comparison for Time 1 versus Time 4 samples

\begin{tabular}{lll}
\hline Variable & Time $1(\mathrm{~N}=211)$ & Time $4(\mathrm{~N}=31)$ \\
\hline Main Mental Health Issue & $39 \%$ & $59 \%$ \\
Anxiety & $33 \%$ & $27 \%$ \\
Depression & & \\
Gender & $30 \%$ & $5 \%$ \\
Male & $68 \%$ & $86 \%$ \\
Female & $2 \%$ & $9 \%$ \\
Transgender & & \\
Ethnic background & $26 \%$ & $32 \%$ \\
Non-white & $74 \%$ & $68 \%$ \\
White & & \\
Status & $63 \%$ & $59 \%$ \\
No transfer & $37 \%$ & $41 \%$ \\
Transfer & & $68 \%$ \\
Residential status & $69 \%$ & $32 \%$ \\
Non-commuter & $31 \%$ & \\
Commuter & & \\
\hline
\end{tabular}




\begin{tabular}{lll}
\hline Parents' education & & \\
Less than 4-year college degree & $30 \%$ & $45 \%$ \\
At least 4-year college degree & $70 \%$ & $55 \%$ \\
Self-reported GPA (range) & $3.4(2.0-4.0)$ & $3.5(2.9-4.0)$ \\
Age, M (range) & $21(18-29)$ & $22(18-30)$ \\
Referral Source & & \\
Self & $61 \%$ & $59 \%$ \\
Other (e.g., family, friend) & $39 \%$ & $41 \%$ \\
Mean Days Waited for Intake & 15 & 14 \\
(range) & $(1-41)$ & $(1-30)$ \\
Full-time Student (12 plus credits) & $97 \%$ & $96 \%$ \\
\hline
\end{tabular}

\subsection{Testing the Hypotheses}

To test both $\mathrm{H} 1$ and $\mathrm{H} 2$ within time correlational analyses are shown in Table 2. For H1, results show that level of mental distress was not related to Institutional Commitment (IC), while mental health concerns was significantly negatively related to IC for two of four time periods. Counseling help belief was positively related to IC for three of four time periods. Collectively these results provide partial support for H1. For H2, IC was positively related to intent to graduate within both Time 1 and 2. In addition, the correlation of Time 1 institutional commitment to Time 2 intent to graduate was significant, i.e., $\underline{r}=.30, \mathrm{n}=64, \mathrm{p}<.01$ (one-tailed), which supports $\mathrm{H} 2$.

Table 2. Means, standard deviations, and correlations among level of mental distress, mental health concerns, counseling help belief and institutional within four separate times ${ }^{\mathrm{a}}$

\begin{tabular}{|c|c|c|c|c|c|c|c|}
\hline \multicolumn{8}{|l|}{ Time $1(\mathrm{~N}=211)$} \\
\hline Variable & $\mathrm{M}$ & $\mathrm{SD}$ & 1 & 2 & 3 & 4 & 5 \\
\hline 1. Level of Mental Distress & 4.85 & 1.09 & --- & & & & \\
\hline 2. Mental Health Concerns & 5.15 & 1.08 & $.49 * *$ & ---- & & & \\
\hline 3. Counseling Help Belief & 6.02 & .74 & -.07 & -.01 & ----- & & \\
\hline 4. Institutional Commitment & 5.54 & 1.41 & -.12 & -.06 & $.17^{*}$ & ----- & \\
\hline 5. Intent to Graduate ${ }^{a}$ & 6.42 & .83 & $-.15^{*}$ & $-.24 * *$ & $.27 * *$ & $.35^{* *}$ & ---- \\
\hline \multicolumn{8}{|l|}{ Time $2(N=64)$} \\
\hline Variable & M & $\mathrm{SD}$ & 1 & 2 & 3 & 4 & 5 \\
\hline 1. Level of Mental Distress & 4.42 & 1.33 & ----- & & & & \\
\hline 2. Mental Health Concerns & 4.79 & 1.35 & $.54 * *$ & ----- & & & \\
\hline 3. Counseling Help Belief & 5.12 & 1.15 & -.22 & $-.42 * *$ & ----- & & \\
\hline 4. Institutional Commitment & 5.63 & 1.42 & -.07 & $-.31 *$ & $.28^{*}$ & ----- & \\
\hline 5. Intent to Graduate ${ }^{a}$ & 6.67 & .50 & .14 & -.10 & $.32 *$ & $.24 *$ & ---- \\
\hline \multicolumn{8}{|l|}{ Time $3(N=48)$} \\
\hline Variable & M & $\mathrm{SD}$ & 1 & 2 & 3 & 4 & \\
\hline 1. Level of Mental Distress & 3.96 & 1.35 & ---- & & & & \\
\hline 2. Mental Health Concerns & 4.15 & 1.29 & $.51^{* *}$ & & & & \\
\hline 3. Counseling Help Belief & 5.50 & 1.19 & $-.29 *$ & $-.35^{*}$ & & & \\
\hline 4. Institutional Commitment & 5.42 & 1.66 & -.03 & -.25 & .03 & ----- & \\
\hline
\end{tabular}




\begin{tabular}{|c|c|c|c|c|c|c|}
\hline \multicolumn{7}{|l|}{ Time $4(\mathrm{~N}=31)$} \\
\hline Variable & $\mathrm{M}$ & SD & 1 & 2 & 3 & 4 \\
\hline 1. Level of Mental Distress & 3.65 & 1.23 & $\begin{array}{ll}---- \\
--1\end{array}$ & & & \\
\hline 2. Mental Health Concerns & 4.23 & 1.27 & $.47^{* *}$ & & & \\
\hline 3. Counseling Help Belief & 5.60 & 1.22 & $-.42 *$ & $-.37 *$ & & \\
\hline 4. Institutional Commitment & 5.83 & 1.31 & -.19 & $-.38^{*}$ & $.35^{*}$ & ---- \\
\hline
\end{tabular}

Note. $* \mathrm{p}<.05 ; * \mathrm{p}<.01$ (two-tailed). Listwise deletion of data within each time.

${ }^{\mathrm{a}}$ Intent to Graduate data only collected at Time 1 and Time 2.

The paired sample t-test for $\mathrm{H} 3$, did not show a significant change in intent to graduate means from time $1(\mathrm{M}=$ $6.63)$ to time $2(\mathrm{M}=6.70), \mathrm{t}(65)=-1.26, \mathrm{p}=.11$. Thus, $\mathrm{H} 3$ is not supported. For $\mathrm{H} 4$, the results are shown in Table 3. Significant overall changes (multivariate F) in the complete sample were found for three of the four variables tested: mental health concerns, counseling help belief, and institutional commitment. Mental health concerns declined, and the mean difference decline between Time $1(\mathrm{M}=5.52)$ and Time $3(\mathrm{M}=4.30)$ was the largest. For the largest difference in groups, the effect size was 1.15 (Cohen, 1988), which is classified as large. Counseling help belief started out strong $(M=6.20)$ but then dropped at Time $2(4.82)$ and then rebounded at Time $3(M=5.54)$ and Time $4(\mathrm{M}=5.64)$. The effect size of .75 (large) was calculated for improvement from Time 2 to Time 4 . For institutional commitment, there was drop from Time 1 to Time 2 but then a steady increase at Time 3 and Time 4 . The increase from Time $2(\mathrm{M}=4.69)$ to Time $4(5.24)$ was significant, and the effect size was .44 (medium). Although the multivariate $\mathrm{F}$ for level of mental distress was not significant $(\mathrm{F}=1.79)$, the descriptive data shows cell mean decreases over time. Overall, there was partial support for H4.

Table 3. General linear model testing significance of outcome variable, post hoc differences within subgroups, and largest effect size for complete sample

\begin{tabular}{|c|c|c|c|c|c|c|c|c|c|c|c|c|c|c|c|c|}
\hline \multirow{2}{*}{$\begin{array}{l}\text { Outcome } \\
\text { Variable }\end{array}$} & \multicolumn{4}{|c|}{ Level of Mental Distress } & \multicolumn{4}{|c|}{ Mental Health Concerns } & \multicolumn{4}{|c|}{ Counseling Help Belief } & \multicolumn{4}{|c|}{ Institutional Commitment } \\
\hline & \multicolumn{4}{|c|}{$\mathrm{F}=1.79$} & \multicolumn{4}{|c|}{$\mathrm{F}=3.38^{*}$} & \multicolumn{4}{|c|}{$\mathrm{F}=4.85^{*}$} & \multicolumn{4}{|c|}{$\mathrm{F}=3.85^{*}$} \\
\hline \multirow[t]{2}{*}{ Cell Means } & $\mathrm{T} 1$ & $\mathrm{~T} 2$ & $\mathrm{~T} 3$ & $\mathrm{~T} 4$ & $\mathrm{~T} 1$ & $\mathrm{~T} 2$ & $\mathrm{~T} 3$ & $\mathrm{~T} 4$ & $\mathrm{~T} 1$ & $\mathrm{~T} 2$ & $\mathrm{~T} 3$ & $\mathrm{~T} 4$ & $\mathrm{~T} 1$ & $\mathrm{~T} 2$ & $\mathrm{~T} 3$ & $\mathrm{~T} 4$ \\
\hline & 4.93 & 4.57 & 3.64 & 3.63 & $5.52^{\mathrm{a}}$ & $5.28^{\mathrm{a}}$ & $4.30^{\mathrm{b}}$ & $4.35^{\mathrm{b}}$ & $6.20^{\mathrm{a}}$ & $4.82^{\mathrm{b}}$ & $5.54^{\mathrm{a}}$ & $5.64^{\mathrm{a}}$ & 4.79 & $4.69^{\mathrm{a}}$ & 5.00 & $5.24^{\mathrm{b}}$ \\
\hline Effect Size $^{\mathrm{d}}$ & & & & & $d=1$. & & & & $d=.7$ & & & & $d=.4$ & & & \\
\hline
\end{tabular}

Note. $\mathrm{N}=15 ; \mathrm{T} 1=$ Time $1 ; \mathrm{T} 2=$ Time 2; $\mathrm{T} 3=$ Time $3 ; \mathrm{T} 4=$ Time 4.

Response scale for all outcome variables, $1=$ strongly disagree to $7=$ strongly agree

${ }^{a, b}$ Within each variable, cell means that do not share the same superscript are significantly different at the 0.05 level by the Least Significant Difference post hoc test.

${ }^{\mathrm{d}}$ Cohen's (1988) effect size, where $d=\mathrm{M}_{1}-\mathrm{M}_{2} /{ }$ pooled SD for largest significant difference within outcome variable groups, except for counseling Help Belief, where $d$ is based on the difference between T2 and T4.

$* \mathrm{p}<.05$ (one-tailed).

\section{Discussion}

To the authors' knowledge, the research design of this study is rare in finding significant correlations among study variables across four time periods for a non-urgent sample of students receiving counseling services; as well as significant changes, with large effect sizes (Cohen, 1988), in two of four variables for the complete counseling sample (mental health concerns, counseling help belief). The decrease in mental health concerns is consistent with clinician rated change in client distress reported in the AUCCD (2016). The robustness of these two findings, despite the loss in client participation over time, is encouraging. The drop in counseling help belief from Time 1 to Time 2 may have been partially due to clients realizing that their mental health concerns were not as "episodic" as 
typically found for college students (Webb \& Widseth, 1988). Despite this drop in counseling help belief, these complete-sample clients continued in therapy, and their belief increased over time.

These overall improvement results are also consistent with Lucas (2012) who found significant improvement in the "highly distressed" undergraduate client sub-sample between intake and their eighth session, and Wolgast et al. (2004) who showed that 14 sessions were needed for clients to show clinically significant change. Such research supports having the resources available in a UCC to avoid "time limited" treatment (Ghetie, 2007). Many college students successfully engage in short-term treatment (Mahon et al., 2015). However, knowing that additional sessions can lead to further benefits in terms of reduced mental health concerns and increased counseling help belief should help to justify a UCC having the resources in place, such as adequate staffing, to avoid having a fixed number or cap of sessions with non-urgent college students (AUCCD, 2016; CCMH, 2017; Lucas, 2012).

What is more unique about this study is the finding that counseling had an overall positive relationship to institutional commitment for the complete sample, and the more limited support that institutional commitment had a positive correlation to intent to graduate. Institutional commitment has been defined as students' feeling that they made the right institutional choice (Davidson et al., 2009), and more general college student research has shown that it is the most proximal antecedent of undergraduate retention (Bean, 1980; Reason, 2009). Focusing on institutional commitment is consistent with prior calls to have UCCs studying variables consistent with more general academic missions and goals (Archer \& Cooper, 1998; Corazzini, 1997). Prior research (Kezar \& Kinsey, 2006) has noted that fostering student commitment to the institution, via their engagement, is generally an important component of a university/college's academic mission. UCCs finding a way to not only show that counseling has mental health benefits, but also benefits for the university/college should allow the UCC to have a more competitive advantage as it competes with other university stakeholders for resources (Hunt et al., 2012).

Two scales, mental health concerns and institutional commitment, were successfully used as shortened versions of longer scales. In addition, a new counseling help belief scale was utilized. All three multi-item scales demonstrated good scale reliabilities. Prior research working with college student samples has suggested that shorter survey length can help with a higher response rate (Fan \& Yan, 2010).

\subsection{Study Limitations}

One study limitation was that intent to graduate data were only collected for the first two time periods. In addition, only non-urgent clients were sampled, and all data were self-reported. However, the biggest limitations of the current study were the generally poor initial response and then the loss in client sample size over time. There were only 15 participants in the complete-data sample. Although such client loss is consistent with prior research (e.g., Draper et al., 2002; Ghetie, 2007; Lucas, 2012; Mahon et al., 2015), it was none-the-less discouraging. The four-year data collection has stopped due to several reasons, including the UCC moving to a new location and some key staff turnover, but general lack of client response was the primary issue. There were a number of reasons illustrating the difficulty of a single UCC collecting a large longitudinal data set. Clearly, many students when given a choice to participate in the research study by the triage therapist said "no". Despite assurances of confidentiality, clients may not have wanted their answers tracked longitudinally. In addition, for those who started the study, archival data from the UCC study site showed that, consistent with the CCMH (2017) report, one is the most frequent number of sessions for a client. Further archival data from the UCC site showed that by 4 sessions (triage plus three sessions after) over $50 \%$ of the non-urgent clients had stopped counseling. Despite the general demographic consistency between the Time 1 and Time 4 samples, the loss in respondents over time is an internal validity threat, complicated by the variability in number of counseling sessions (and time ranges) between the fixed data collection time intervals after triage. In addition, the percentage of clients reporting anxiety as their main mental health issue increased considerably from Time 1 to Time 4 , and the percentage of female (male) clients increased (decreased).

University growth in student enrollment over the last four years has led to more on-campus and close-to-campus housing making the UCC's counseling services more accessible. This student-growth and greater accessibility has led to increased demand for the UCC's counseling services over the past several years (e.g., 34\% increase in intakes, $37 \%$ increase in individual counseling), without the needed increase in UCC professional staff to meet the recommended ICAS ratio of 1 FTE professional staff to every 1,000 to 1,500 students (IACS, 2010). For such an under-staffed UCC, voluntary client research would be expected to have a lower priority. Despite the UCC Director and several staff being supportive, it is probably safe to assume that many already-stressed triage therapists never asked students initially if they were interested in study participation. As Cooper and Archer (2002) noted 15 years ago, "the mission of counseling centers is primarily service, and the reward structure for individuals 
and centers does not typically encourage research and scholarly writing" (p. 57). In addition, the lead author was not part of the UCC professional staff, but instead an "outside" faculty member. Although in-person progress reports on data collection during each regular semester were given by the lead author at UCC staff meetings, as well as other periodic updates, research project visibility to the staff undoubtedly suffered due to higher priorities. Offering a money-incentive, as noted in the Methods section, part-way through the data collection did not improve client participation. One solution to the difficulty of a single UCC collecting sufficient data is for the UCC to become part of a larger research network so that common data collection from multiple UCCs can be aggregated (Kopta et al., 2014).

\subsection{Implications for Practicing College Clinicians and Resourcing UCCs}

For practicing UCC counselors, the findings that over time counseling help belief rebounded, as well as institutional commitment increased, both support the therapist not having to cap the number of sessions with a non-urgent client (AUCCD, 2016). These findings reinforce the benefits of an open-ended psychotherapy process (Pinkerton et al., 2009). As part of this process, the study results also support the therapist being able to spread out counseling sessions over time if necessary (Surette \& Shier, 2017).

Scientifically demonstrating to University administration that the on-campus UCC site can help undergraduates in distress should ideally help the UCC to increase its allocation of university-based resources (Bishop, 2010; Hunt et al., 2012). Such research efforts need to be continued as UCCs compete with other university stakeholders for resources (Castonguay, Locke, \& Hayes, 2011). However, beyond more traditional measures such as the BMH (Kopta et al., 2014) or CCAPS (Brunner et al., 2014), UCC-site research efforts which also incorporate variables more directly linked to the academic mission of a university or college, are needed. It may be necessary for a particular UCC to demonstrate to its University Administration that counseling benefits the University's student retention and immediate retention-antecedents, such as institutional commitment. By showing that a UCC not only reduces its' students mental health concerns, but also helps to meet a university's academic goals, this should help the UCC to get the resources needed to keep up with increasing routine as well as non-routine student mental health demands.

\section{References}

AUCCD. (2016). The association for university and college counseling center directors annual Survey. Retrieved from http://www.aucccd.org/assets/../aucccd\%202016\%20monograph\%20-\%20public.pdf

Bean, J. P. (1980). Dropouts and turnover: The synthesis and test of a causal model of student attrition. Research in Higher Education, 12(2), 155-187. https://doi.org/10.1007/BF00976194

Bergin, A., \& Garfield, S. (2013). Handbook of psychotherapy and behavior change (6th ed.). New York, N.Y.: John Wiley \& Sons.

Bishop, J. B. (2010). The counseling center: An undervalued resource in recruitment, retention and risk management. Journal of College Student Psychotherapy, 24, 248-260. https://doi.org/10.1080/87568225.2010.509219

Blau, G., DiMino, J., Abreu, I., \& LeLeux-LaBarge, K. (in press-b). Testing the impact of counseling over time on non-urgent undergraduate life satisfaction. Journal of Educational and Developmental Psychology, 7(2), 59. https://doi.org/10.5539/jedp.v7n2p59

Blau, G., DiMino, J., DeMaria Jr., P., Beverly, C., \& Chessler, M. (in press-a). Mental health concerns' impact on graduation intent and improvement for brief counseling. Journal of Assessment and Institutional Effectiveness.

Blau, G., DiMino, J., DeMaria, P. A. Jr., Beverly, C., Chessler, M., \& Drennan, R. Jr. (2016). Social connectedness and life satisfaction: Comparing mean levels for two undergraduate samples and testing for improvement based on brief counseling. Journal of American College Health, 64(8), 585-592. https://doi.org/10.1080/07448481.2016.1207645

Blau, G., DiMino, J., Sheridan, N., Stein, A., Casper, S., Chessler, M. \& Beverly, C. (2015). Wait time for counseling affecting perceived stigma and attitude toward the University. College Student Journal, 49(2), 280-290.

Brunner, J. L., Wallace, D. L., Reymann, L. S., Sellers, J.-J., \& McCabe, A. G. (2014). College counseling today: Contemporary students and how counseling centers meet their needs. Journal of College Student Psychotherapy, 28, 257-324. https://doi.org/10.1080/87568225.2014.948770 
Castonguay, L. G., Locke, B. D., \& Hayes, J. A. (2011). The Center for Collegiate Mental Health: An example of a practice-research network in university counseling centers. Journal of College Student Psychotherapy, 25(2), 105-119. https://doi.org/10.1080/87568225.2011.556929

CCMH. (2017). Center for collegiate mental health: 2016 Annual report. Penn State (Publication No. STA 17-74). https://sites.psu.edu/ccmh/files/2017/01/2016-Annual-Report-FINAL_2016_01_09-1gc2hj6.pdf

Cohen, J. (1988). Statistical Power Analysis for the Behavioral Sciences (2nd ed.). Hillsdale, NJ: Lawrence Earlbaum Associates.

Coll, K. M., \& Stewart, R. A. (2002). Collaboration between counseling services and an academic program: An exploratory study of student outcome. Journal of College Counseling, 5, 135-141. https://doi.org/10.1002/j.2161-1882.2002.tb00215.x

Cooper, S. E., \& Archer, J. A. Jr. (2002). Evaluation and research in college counseling center contexts. Journal of College Counseling, 5, 50-59. https://doi.org/10.1002/j.2161-1882.2002.tb00206.x

Corazzini, J. (1997). Using research to determine the efficacy and modes of treatment in University Counseling Centers: Comment on the Jobes, Jacoby, Cimbolic, and Hustead (1997) and Hayes (1997). Journal of Counseling Psychology, 44(4), 378-380. https://doi.org/10.1037/0022-0167.44.4.378

Davidson, W. B., Beck, H. P., \& Milligan, M. (2009). The College Persistence Questionnaire: Development and validation of an instrument that predicts student attrition. Journal of College Student Development, 50(4), 373-390. https://doi.org/10.1353/csd.0.0079

Draper, M. R., Jennings, J., Baron, A., Erdur, O., \& Shankar, L. (2002). Time-limited counseling outcome in a nationwide college counseling center sample. Journal of College Counseling, 5(1), 26-38. https://doi.org/10.1002/j.2161-1882.2002.tb00204.x

Fan, W., \& Yan, Z. (2010). Factors affecting response rates of the web survey: A systematic review. Computers in Human Behavior, 26(2), 132-139. https://doi.org/10.1016/j.chb.2009.10.015

Gallagher, R. P. (2014). National Survey of Counseling Center Directors. Retrieved December 28, 2016, from http://www.iacsinc.org/

Ghetie, D. (2007). The debate over time-limited treatment in college counseling centers. Journal of College Student Psychotherapy, 22(1), 41-61. https://doi.org/10.1300/J035v22n01_04

Green, J. L., Lowry, J. L., \& Kopta, M. (2003). College students versus college counseling center clients. Journal of College Student Psychotherapy, 17(4), 25-37. https://doi.org/10.1300/J035v17n04_05

Hausmann, L. R., Ward Schofield, J., \& Woods, R. L. (2007). Sense of belonging as a predictor of intentions to persist among African American and White first-year college students. Research in Higher Education, 48(7), 803-839. https://doi.org/10.1007/s11162-007-9052-9

IACS. (2010). Accreditation for the university and college counseling services. Alexandria, VA: International Association of Counseling Services, Inc.

Hu, Y. J., Stewart-Brown, S., Twigg, L., \& Weich, S. (1997). Can the 12-item General Health Questionnaire be used to measure positive mental health? Psychological Medicine, 37(7), 1005-1013. https://doi.org/10.1017/S0033291707009993

Hunt, J. B., Watkins, D., \& Eisenberg, D. (2012). How do college campuses make decisions about allocating resources for student mental health? Findings from key participant interviews. Journal of College Student Development, 53(6), 850-856. https://doi.org/10.1353/csd.2012.0083

Kezar, A., \& Kinzie, J. (2006). Examining the ways institutions create student engagement: The role of mission. Journal of College Student Development, 47(2), 149-172. https://doi.org/10.1353/csd.2006.0018

Kitzrow, M. A. (2009). The mental health needs of today's college students: Challenges and recommendations. NASPA Journal, 46(4), 646-660. https://doi.org/10.2202/1949-6605.5037

Kopta, S. M., Petrik, M. L., Saunders, S. M., Mond, M., Hirsch, G., Kadison, R., \& Raymond, D. (2014). The utility of an efficient outcomes assessment system at university counseling centers. Journal of College Student Psychotherapy, 28, 97-116. https://doi.org/10.1080/87568225.2014.883876 
Lambert, M. J., Hansen, N. B., Umphress, V., Lunnen, K., Okiishi, J., Burlingame, G. M., \& Reisinger, C. W. (1996). Administration and scoring manual for the OQ-45.2 (Outcome Questionnaire). American Professional Credentialing Services, LLC.

Lee, D., Olson, E. A., Locke, B., Testa Michelson, S., \& Odes, E. (2009). The effects of college counseling services on academic performance and retention. Journal of College Student Development, 50(3), 305-319. https://doi.org/10.1353/csd.0.0071

Lucas, M. S. (2012). Counseling on campus: Client persistence and progress. Journal of College Student Psychotherapy, 26, 227-240. https://doi.org/10.1080/87568225.2012.685856

Mahon, M., Laux, J. M., McGuire Wise, S., Ritchie, M. H., Piazza, N. J., \& Tiamiyu, M. (2015). Brief therapy at a university counseling center: Working alliance, readiness to change, and symptom severity. Journal of College Counseling, 18, 223-243. https://doi.org/10.1002/jocc.12017

Maffini, C. S., \& Toth, P. L. (2017). Quality improvement in university counseling centers. Journal of College Student Psychotherapy, 31(1), 43-58. https://doi.org/10.1080/87568225.2016.1254000

Mowbray, C., Megivern, D., Mandiberg, J., Strauss, S., Stein, C., Collins, K. ... Lett, R. (2006). Campus mental health services: Recommendations for change. American Journal of Orthopsychiatry, 76(2), 226-237. https://doi.org/10.1037/0002-9432.76.2.226

Paulson, B., Truscott, D., \& Stuart, J. (1999). Clients' perceptions of helpful experiences in counseling. Journal of Counseling Psychology, 46(3), 317-324. https://doi.org/10.1037/0022-0167.46.3.317

Pinkerton, R., Talley, J. E., \& Cooper, S. L. (2009). Reflections on individual psychotherapy with university students: What seems to work. Journal of College Student Psychotherapy, 23, 153-171. https://doi.org/10.1080/87568220902793830

Reason, R. D. (2009). Student variables that predict retention: Recent research and new developments. NASPA Journal, 46(3), 482-501. https://doi.org/10.2202/1949-6605.5022

SPSS. (2013). Statistical package for the social sciences (Version 22). Armonk, NY: IBM.

Stevens, J. (1996). Applied Multivariate Statistics for the Social Sciences (3rd ed.). Mahwah, NJ: Erlbaum.

Surette, T. E., \& Shier, M. L. (2017). A common factors approach to supporting university students experiencing psychological distress. Journal of College Student Psychotherapy, 31(2), 112-131. https://doi.org/10.1080/87568225.2016.1248233

Tinto, V. (1975). Dropout from higher education: A theoretical synthesis of recent research. Review of Educational Research, 45(1), 89-125. https://doi.org/10.3102/00346543045001089

Webb, R., \& Widseth, J. (1988). Facilitating students' going into and stepping back from their inner worlds: Psychotherapy and the college student. Journal of College Student Psychotherapy, 3(1), 5-15. https://doi.org/10.1300/J035v03n01_02

Wilson, S. B., Mason, T. W., \& Ewing, M. J. (1997). Evaluating the impact of receiving university-based counseling services on student retention. Journal of Counseling Psychology, 44(3), 316-320. https://doi.org/10.1037/0022-0167.44.3.316

Wolgast, B. M., Lambert, M. J., \& Puschner, B. (2004). The dose-response relationship at a college counseling center. Journal of College Student Psychotherapy, 18(2), 15-29. https://doi.org/10.1300/J035v18n02_03

\section{Copyrights}

Copyright for this article is retained by the author(s), with first publication rights granted to the journal.

This is an open-access article distributed under the terms and conditions of the Creative Commons Attribution license (http://creativecommons.org/licenses/by/4.0/). 